\title{
5-HT Inhibits Calcium Current and Synaptic Transmission from Sensory Neurons in Lamprey
}

\author{
Abdeljabbar EI Manira, Weiqi Zhang, Erik Svensson, and Nathalie Bussières \\ The Nobel Institute for Neurophysiology, Department of Neuroscience, Karolinska Institutet, \\ S-171 77 Stockholm, Sweden
}

\begin{abstract}
In the lamprey spinal cord, 5-hydroxytryptamine (5-HT) immunoreactivity (ir) is present in the ventromedial plexus originating from intraspinal neurons, ventrolateral column arising from the brainstem, and dorsal column. The latter 5-HT system originates from small dorsal root ganglion neurons. Combined Lucifer yellow intracellular labeling of the intraspinal sensory neurons, dorsal cells, and 5-HT immunohistochemistry showed close appositions between 5-HT-ir fibers and dorsal cell axons. Application of 5-HT depressed monosynaptic EPSPs evoked in giant interneurons by stimulation of single dorsal cells, dorsal roots, or dorsal column without any detectable change in the input resistance of postsynaptic neurons. Furthermore, the amplitude of AMPA-evoked depolarizations in giant interneurons was unaffected by $5-\mathrm{HT}$. The lack of postsynaptic effects of 5-HT indicates that the decrease of the amplitude of sensory
\end{abstract}

monosynaptic EPSPs by $5-\mathrm{HT}$ is mediated by presynaptic mechanisms. The inhibition of monosynaptic EPSPs by $5-\mathrm{HT}$ was not counteracted by an antagonist of $5-\mathrm{HT}_{1 \mathrm{~A}}$ receptors. 5 - HT also reduced the amplitude of the calcium current recorded in isolated dorsal cells and slowed down its kinetics. The inhibition of calcium channels could represent the mechanism mediating the depression of synaptic transmission at the axonal level. These results show that activation of 5-HT receptors on dorsal cell axons as well as on other sensory neurons mediates inhibition of sensory synaptic transmission to giant interneurons. In intact animals, 5-HT could be released from small 5-HT neurons in dorsal root ganglia, which thus may underlie direct sensory-sensory interactions.

Key words: synaptic transmission; 5-HT; presynaptic inhibition; modulation; calcium channels; spinal cord; locomotion
The flexibility of neural circuits generating motor activity depends on their ability to modulate the operation of the different components, such as firing properties of single neurons, sensitivity to transmitters, and the strength of synaptic transmission (for review, see Harris-Warrick and Marder, 1991; Grillner et al., 1995; Katz and Frost, 1996). Presynaptic modulation of synaptic transmission provides a mechanism for a local control of the excitability of different neurons close to the synaptic release site. The amount of transmitter released from network neurons thus can be enhanced or reduced without altering the responsiveness of postsynaptic neurons to other inputs. Such a modulation represents an important control mechanism for reconfiguration and adaptation of neural circuits, depending on the state of the animal.

5-Hydroxytryptamine (5-HT, serotonin) constitutes a major neuromodulator in the nervous system of vertebrates and invertebrates (Welsh and Moorhead, 1960; Anwyl, 1990; Jacobs and Fornal, 1993; Saudou and Hen, 1994). In the spinal cord, 5-HT can act on the soma-dendritic level to modulate the firing properties of neurons (Hounsgaard and Kiehn, 1989; Wallén et al., 1989; Sillar and Simmers, 1994a) and to change the frequency of locomotion (HarrisWarrick and Cohen, 1985; Christenson et al., 1989; Barbeau and Rossignol, 1990; Sillar et al., 1992). 5-HT also can mediate presyn-

Received Sept. 9, 1996; revised Dec. 9, 1996; accepted Dec. 11, 1996.

This work was supported by the Swedish Medical Research Council (project 11562), Jeanssons Stiftelse, and Åke Wibergs Stiftelse. We thank Drs. L. Brodin, S Grillner, P. Krieger, and P. Wallén for their comments on this manuscript. We also thank H. Axegren and M. Bredmyr for skillful technical assistance.

Correspondence should be addressed to Dr. A. El Manira, The Nobel Institute for Neurophysiology, Department of Neuroscience, Karolinska Institutet, S-171 77 Stockholm, Sweden.

Dr. Zhang's present address: Center of Physiology and Pathophysiology, Department of Neurophysiology, Georg-August University, D-37073 Göttingen, Germany Copyright (C) 1997 Society for Neuroscience $0270-6474 / 97 / 171786-09 \$ 05.00 / 0$ aptic modulation of synaptic transmission through presynaptic facilitation (Dale and Kandel, 1990; Mintz and Korn, 1991; Katz et al., 1994; Hori et al., 1996) or presynaptic inhibition (Buchanan and Grillner, 1991; Johnson et al., 1992; Sillar and Simmers, 1994b). In mammals, 5-HT has been shown to inhibit calcium currents in spinal cord neurons (Sah, 1990), but little is known about its effect on synaptic transmission from these neurons.

In the lamprey spinal cord, 5-HT arises from three different systems. Spinal 5-HT neurons, which also colocalize dopamine, form a ventromedial plexus with varicosities that do not make any output synapses (Christenson et al., 1990; Schotland et al., 1996). Descending 5-HT axons originate from the brainstem and project in the lateral and ventral columns (Harris-Warrick et al., 1985; Brodin et al., 1988; Zhang et al., 1996). Finally, dorsal column 5-HT axons arise from dorsal root ganglion neurons (Van Dongen et al., 1985; Brodin et al., 1988; Zhang et al., 1996). 5-HT depresses the postspike slow afterhyperpolarization (Wallén et al., 1989) and increases ventral root burst duration during locomotion (Harris-Warrick and Cohen, 1985; Christenson et al., 1989). These effects are mediated by activation of $5-\mathrm{HT}_{1 \mathrm{~A}}$-like receptors (Wikström et al., 1995). 5-HT also has been shown to modulate synaptic transmission from reticulospinal axons via presynaptic inhibition (Buchanan and Grillner, 1991; Shupliakov et al., 1995). Synaptic transmission from excitatory and inhibitory interneurons is, however, not affected by 5-HT (Buchanan and Grillner, 1991; Matsushima and Grillner, 1992).

In this study, we examine the involvement of the dorsal column 5-HT axons in modulating excitatory transmission from sensory neurons. Intraspinal cutaneous sensory neurons (dorsal cells), as well as other sensory neurons, make glutamatergic synapses with spinobulbar relay interneurons (giant interneurons; Rovainen, 

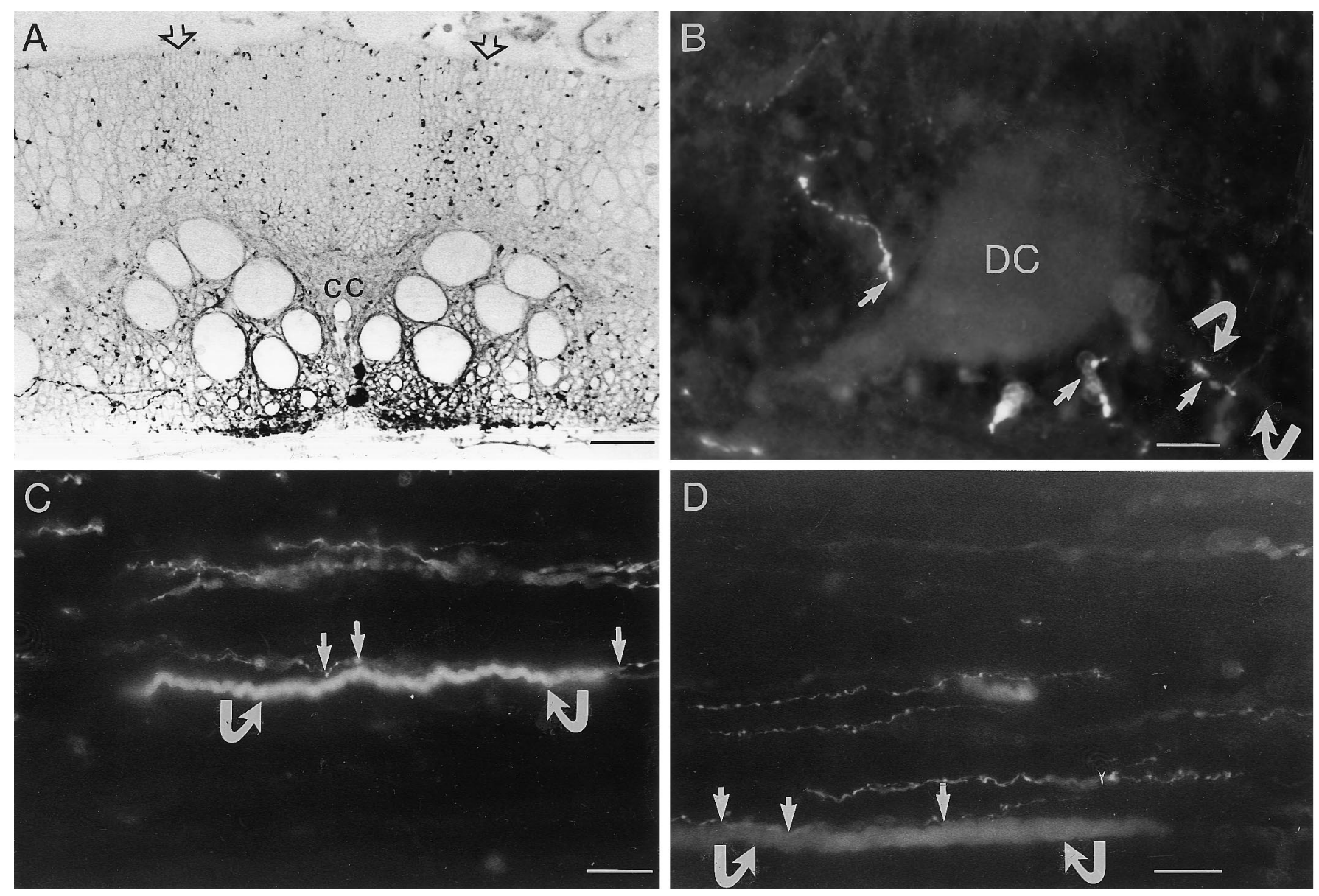

Figure 1. 5-HT-immunoreactive (ir) fibers make close appositions with dorsal cell axons. $A$, A transverse section of the lamprey spinal cord showing 5-HT immunoreactivity. The dorsal column is richly innervated with 5-HT-ir fibers, which enter through dorsal roots (open arrows). Ventral to the central canal $(c c)$, intrinsic 5-HT neurons give rise to the ventral plexus. B, A horizontal section of the spinal cord showing a dorsal cell $(D C)$ filled with Lucifer yellow and immunoreactivity against 5-HT. Close appositions were found between 5-HT-ir varicose fibers and the cell body of the dorsal cell (arrows). Close appositions also were found on the proximal axon (curved arrows). $C, D$, Double-exposure photomicrographs for both Texas Red and Lucifer yellow. Dorsal cells were filled with Lucifer yellow, and the preparation was fixed and used for 5-HT immunoreactivity. 5-HT-ir fibers project in the dorsal column and make close appositions (arrows) with dorsal cell axons (curved arrows). Scale bars: $A, 60 \mu \mathrm{M} ; B-D, 20 \mu \mathrm{M}$.

1967; Brodin et al., 1987; Christenson and Grillner, 1991). The effects of 5-HT on sensory transmission were analyzed at these glutamatergic synapses. We show that 5-HT reduces the amplitude of monosynaptic EPSPs and inhibits calcium influx in dorsal cells. These effects could be mediated by 5-HT released from sensory fibers in the dorsal column, which make close appositions with somata and axons of dorsal cells.

\section{MATERIALS AND METHODS}

Experiments were performed on adult lampreys (Lampetra fluviatilis), which were anesthetized with tricaine methane sulfonate (MS-222; 100 $\mathrm{mg} / \mathrm{l})$. The caudal spinal cord, where the giant interneurons are located (Rovainen, 1967), was dissected free from the notochord and mounted dorsal side up in a cooled $\left(8-12^{\circ} \mathrm{C}\right)$ SYLGARD-lined chamber, which was perfused continuously with physiological Ringer's solution with the following concentration (in $\mathrm{mm}$ ): $138 \mathrm{NaCl}, 2.1 \mathrm{KCl}, 1.8 \mathrm{CaCl}_{2}, 1.2$ $\mathrm{MgCl}_{2}, 4$ glucose, 2 HEPES, and 0.5 L-glutamine. The Ringer's was bubbled with $\mathrm{O}_{2}$ and the $\mathrm{pH}$ adjusted to 7.4 with $\mathrm{NaOH}$.

Immunohistochemical experiments. Intraspinal sensory cutaneous neurons (dorsal cells) were impaled with glass microelectrodes filled with 5\% Lucifer yellow in $0.1 \mathrm{M} \mathrm{LiCl}$. Lucifer yellow then was injected iontophoretically into dorsal cells, and the spinal cord was fixed for $1.5 \mathrm{hr}$ in $4 \%$ paraformaldehyde in $0.1 \mathrm{M}$ phosphate buffer $(\mathrm{PB}), \mathrm{pH} 7.4$, with $0.2 \%$ picric acid. After fixation, the spinal cord was cryoprotected in 15 and $30 \%$ sucrose in PB, mounted in embedding medium (Tissue-Tek, Miles, Elkhart, IN), frozen with $\mathrm{CO}_{2}$, and longitudinally sectioned at $12 \mu \mathrm{m}$ in a Leitz 1720 digital cryostat. Sections were mounted on gelatin-coated slides and rinsed $(2 \times 10 \mathrm{~min})$ with $0.1 \mathrm{M}$ PBS. The sections subsequently were incubated in a humid chamber in a polyclonal 5-HT antibody (Steinbusch et al., 1987) diluted 1:1000 in $0.1 \mathrm{M}$ PBS at $\mathrm{pH} 7.3$ with $0.3 \%$ Triton X-100 for 16-20 hr. They were rinsed with PBS $(2 \times 10 \mathrm{~min})$ and incubated in donkey anti-rabbit antiserum coupled to Texas Red (Jackson ImmunoResearch, West Grove, PA) diluted 1:40 in 0.1 M PBS at pH 7.3 with Triton X-100 for $1 \mathrm{hr}$ at room temperature. Then sections were mounted in glycerol and coverslipped. The staining was studied and photographed with a Nikon fluorescence microscope. If Lucifer yellowfilled dorsal cells and 5-HT fibers were in the same focal depth with no detectable gap in between, it was referred to as close appositions.

Electrophysiology experiments. Intracellular recordings were made from giant interneurons and dorsal cells using thin-walled glass microelectrodes filled with $\mathrm{K}$ acetate $(4 \mathrm{M})$. The two types of neurons were identified by their characteristic shape and position in the spinal cord. Unitary monosynaptic EPSPs were elicited in giant interneurons by simultaneously recording and stimulating presynaptic dorsal cells. Compound monosynaptic EPSPs were elicited by stimulation of either ipsilateral dorsal roots or dorsal column axons using suction electrodes. In experiments with dorsal column stimulation, lateral transverse lesions of the spinal cord were made from the border of the dorsal column to the lateral margin on the ipsilateral side and from the midline to the lateral margin of the spinal cord. This eliminated the spread of the current to axons and neurons outside the dorsal column. To minimize polysynaptic transmission, we used high-divalent cation Ringer's (with the following composition in mM: $120 \mathrm{NaCl}, 2.1 \mathrm{KCl}, 10.8 \mathrm{CaCl}_{2}, 7.2 \mathrm{MgCl}_{2}, 4$ glucose, 

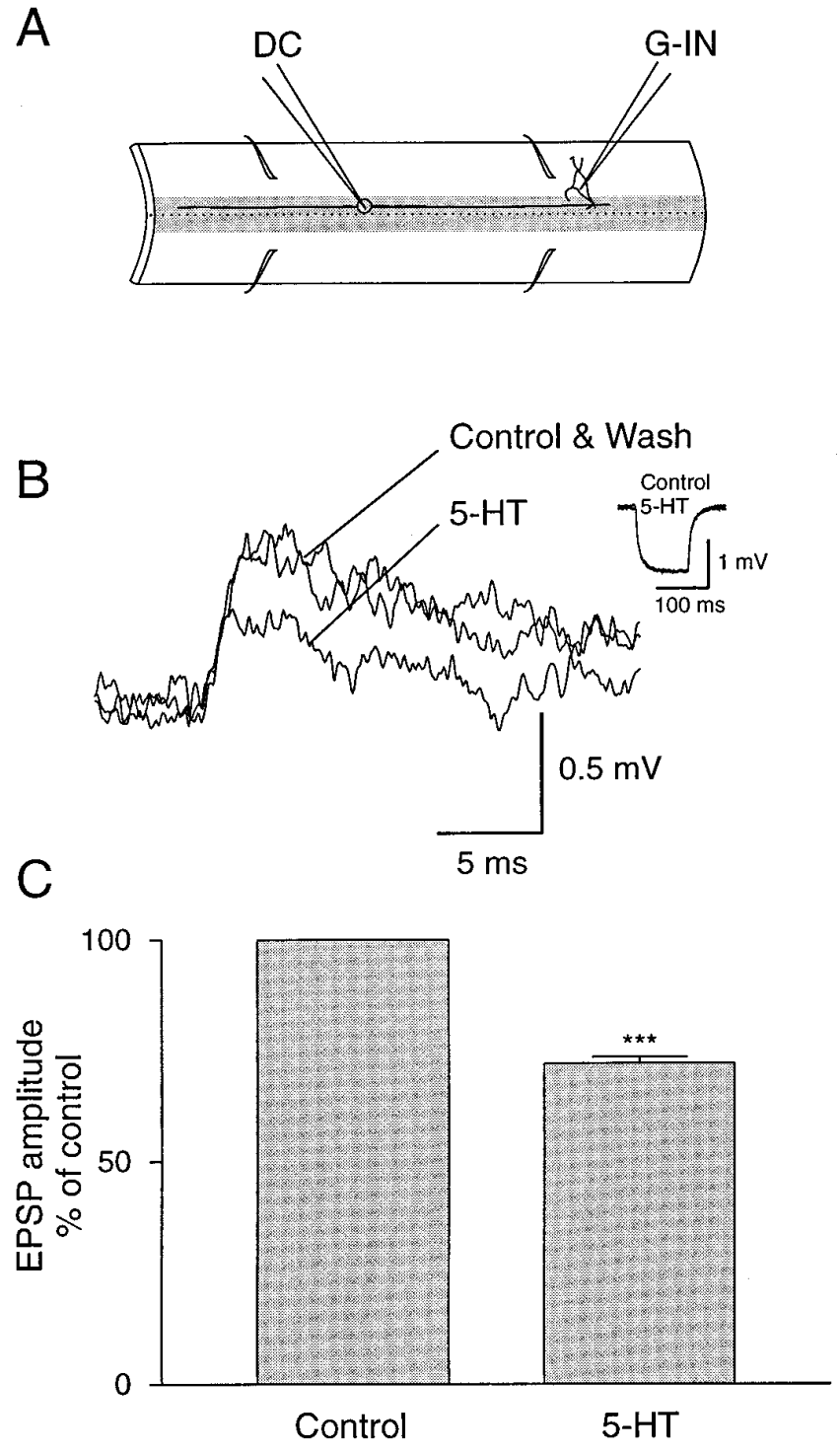

Figure 2. 5-HT depresses dorsal cell synaptic transmission. A, Paired intracellular recordings were made from a presynaptic dorsal cell $(D C)$ and a postsynaptic giant interneuron $(G-I N) . B$, The amplitude of the monosynaptic EPSP elicited in the giant interneuron by stimulation of a dorsal cell was reversibly reduced after application of 5-HT (5 $\mu \mathrm{M})$. Traces are averages of 10 sweeps. Inset, The input resistance of the postsynaptic neuron was not affected by 5-HT. C, Average effect of 5-HT from three different pairs of neurons. The asterisks indicate statistical significance $(p<0.0001)$.

2 HEPES, and 0.5 L-glutamine, with $\mathrm{pH}$ adjusted to 7.4 with $\mathrm{NaOH}$ ) in these experiments. Strychnine $(5 \mu \mathrm{M})$ also was added to the high-divalent cation Ringer's to block glycinergic inhibition. EPSPs in giant interneurons were recorded in discontinuous current clamp using an Axoclamp 2A (Axon Instruments, Foster City, CA). Axon Instrument software (pClamp) was used for data acquisition and analysis on a 486 PC computer equipped with an A/D interface (Digidata 1200).

Cell dissociation. Larval lampreys (Petromyzon marinus) were used for culture of dorsal cells. The animals were anesthetized, eviscerated, and dissected in cooled, oxygenated physiological solution (see above). To label sensory dorsal cells with fluorescein-coupled dextran amines (FDA), we opened the notochord ventrally to cut all ventral roots while leaving the dorsal roots intact. FDA was applied to the cut muscles along the notochord, and the preparation subsequently was washed with Ringer's to remove excess FDA. After $48 \mathrm{hr}$ of transport time at $8^{\circ} \mathrm{C}$ to allow labeling of dorsal cells, the spinal cord was dissected and incubated at room temperature in collagenase $(2 \mathrm{mg} / \mathrm{ml}, 30 \mathrm{~min}$; Sigma, St. Louis, MO) and then in protease $(2 \mathrm{mg} / \mathrm{ml}, 45 \mathrm{~min}$; Sigma) diluted in Leibovitz's L-15 culture medium (Sigma). Thereafter the spinal cord was washed with culture medium and triturated through a sterilized pipette. The supernatant containing the dissociated cells was distributed in $35 \mathrm{~mm}$ Petri dishes (Falcon, Oxnard, CA) that contained $2 \mathrm{ml}$ of the culture medium. The dissociated neurons were incubated at $10^{\circ} \mathrm{C}$ for $1-15 \mathrm{~d}$, and the medium was changed every $3 \mathrm{~d}$.

Whole-cell recordings were performed from FDA-labeled dorsal cells using an Axopatch 200A patch-clamp amplifier. Cells were clamped at a holding potential of $-90 \mathrm{mV}$, and currents were evoked by $40-60 \mathrm{msec}$ depolarizing voltage steps applied at $10 \mathrm{sec}$ intervals. Linear leak and residual capacity currents were subtracted on-line with a $\mathrm{P} / 4$ subtraction protocol (4 steps, one-fourth of the test pulse, averaged and scaled for each test pulse). Pulse protocols, data acquisition, and analysis of recordings were performed with pClamp software (Axon Instruments). During the recording, the cells were perfused through a gravity-driven system with a solution containing (in $\mathrm{mM}$ ): $\mathrm{NaCl} 114$, TEA $10, \mathrm{KCl} 1, \mathrm{MgCl}_{2} 1.2$, glucose, HEPES $10, \mathrm{BaCl}_{2} 5$, and TTX 0.001, with pH adjusted to 7.4. For whole-cell recordings, the pipettes were filled with a solution containing (in $\mathrm{mM}$ ): $\mathrm{CsCH}_{3} \mathrm{SO}^{3-} 110$, EGTA 10 , glucose 10 , HEPES $10, \mathrm{MgCl}_{2}$ 5, $\mathrm{CaCl}_{2}$ 1, ATP 2, GTP 0.4, and phosphocreatinine 8, pH 7.4 adjusted with $\mathrm{CsOH}$.

Drugs. The following drugs were used during this study: $(R S)$ - $\alpha$-amino3-hydroxy-5-methyl-4-isoxazolepropionic acid (AMPA; Tocris Cookson, Bristol, UK), 5-hydroxytryptamine (5-HT; Sigma), S(-)-UH-301 (gift from Astra, Stockholm, Sweden), and tetrodotoxin (TTX; Sigma). Unless otherwise stated, the different agonists and antagonists were added to the perfusing solution. Results are expressed as mean \pm SEM. Student's $t$ test was used for statistical comparisons.

\section{RESULTS \\ 5-HT-immunoreactive fibers make close appositions with dorsal cell axons}

The dorsal column contains 5-HT-immunoreactive (ir) axons that originate from dorsal root ganglion neurons (Fig. 1A). To detect possible contacts between the intraspinal skin sensory neurons (dorsal cells) and 5-HT-ir axons in the dorsal column, we combined intracellular labeling of identified dorsal cells and 5-HT immunohistochemistry. The presence of close appositions was examined by switching between filters for Lucifer yellow and Texas Red. Figure $1 B$ shows a horizontal section of the spinal cord above the central canal with varicose 5-HT-ir fibers making close appositions with a dorsal cell. Close appositions were found both on the cell body and the proximal part of the axons (Fig. $1 B$ ). Figure $1 C, D$ shows horizontal sections at the level of the dorsal column with Lucifer yellow-labeled dorsal cell axons making close appositions with 5-HT-ir fibers. 5-HT-ir varicosities thus were found on both dorsal cell axons and cell bodies, and a majority of close appositions were distributed along the length of the axons (Fig. 1C,D). 5-HT in the dorsal column might be released in a paracrinic manner, because no 5-HT output synapses have been found in the spinal cord (Christenson et al., 1990).

\section{5-HT depresses dorsal cells, dorsal roots, and dorsal column transmission to giant interneurons}

The existence of close appositions between 5-HT-ir fibers and dorsal cells axons suggests that synaptic transmission from dorsal cells can be modulated presynaptically by $5-\mathrm{HT}$. This was tested by using paired intracellular recordings from dorsal cells and their postsynaptic target neurons, giant interneurons (Fig. 2A; Rovainen, 1967; Brodin et al., 1987). Bath application of 5-HT (1-5 $\mu \mathrm{M})$ consistently and reversibly decreased the amplitude of unitary monosynaptic EPSPs in giant interneurons evoked by dorsal cell stimulation (Fig. $2 B$ ). The amplitude of the monosynaptic EPSPs was reduced by $28.0 \% \pm 2.5 \%(n=3$ of $3 ; p<0.0001$; Fig. $2 C)$. This effect of 5 -HT occurred without any measurable change in the input resistance of giant interneurons (Fig. 2B, inset), suggesting that the effect of 5-HT is mediated by presynaptic mechanisms. 

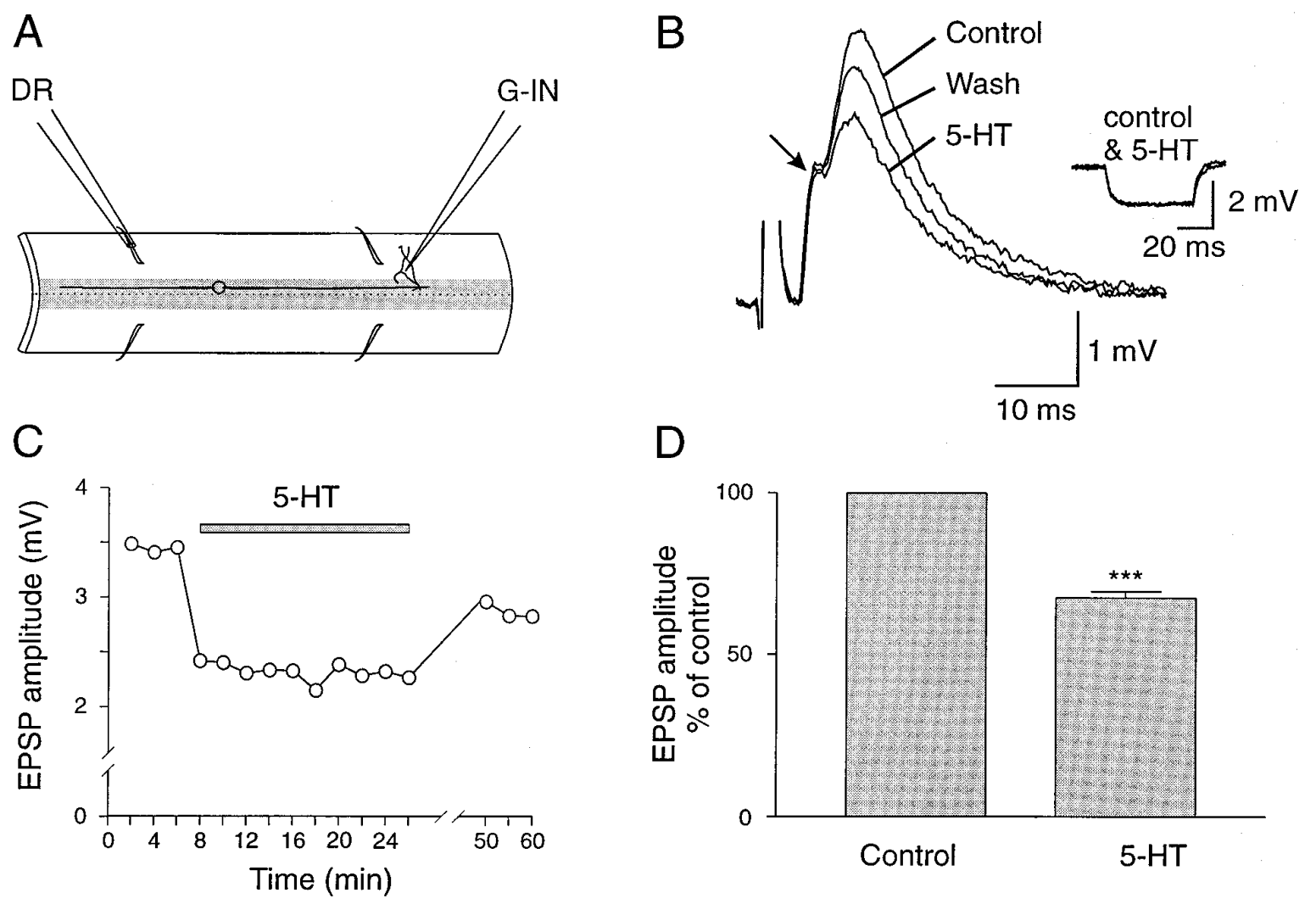

Figure 3. 5-HT reduces the amplitude of dorsal root-evoked monosynaptic EPSPs. $A$, Compound monosynaptic EPSPs were elicited in giant interneurons $(G-I N)$ by stimulation of an ipsilateral dorsal root $(D R)$. $B$, The amplitude of the chemical component of dorsal root-evoked EPSP was depressed by 5-HT $(5 \mu \mathrm{M})$, whereas the electrical component was not significantly affected. Traces are averages of 30 sweeps. Inset, No change was observed in the input resistance of the postsynaptic neuron during application of 5-HT. $C$, The effect of 5-HT showed a fast onset and required a long washout before recovery. $D$, Average effect of 5-HT on dorsal root-evoked EPSPs in six different giant interneurons. The asterisks indicate statistical significance $(p<0.0001)$.

To determine whether 5-HT depresses synaptic transmission from sensory afferents, we stimulated dorsal roots and recorded compound monosynaptic EPSPs in giant interneurons (Fig. 3A). In some giant interneurons the compound EPSP showed an electrical component (Fig. 3B). 5-HT (1-5 $\mu \mathrm{M})$ reversibly reduced the amplitude of the chemical component of the compound EPSP, although the electrical component and the input resistance remained unchanged (Fig. 3B). The effect of 5-HT showed a fast onset with the maximum reduction of the amplitude of the EPSP occurring within 4 min of 5-HT application (Fig. 3C). The amplitude of the EPSP always recovered, but long periods of washout were needed (Fig. $3 C$ ). Similar effects of 5 -HT on dorsal rootevoked EPSPs were seen in all giant interneurons tested (Fig. 3D; $n=6$; mean EPSP reduction $=32.5 \% \pm 2 \% ; p<0.0001$ ).

5-HT also decreased the amplitude of EPSPs elicited by stimulation of the dorsal column (Fig. $4 A$ ), which contains axons of dorsal cells as well as the descending and ascending branch of other sensory afferents. The depression of the amplitude of the monosynaptic EPSP occurred without any change of the membrane input resistance of giant interneurons (Fig. 4B). As for dorsal root EPSPs, the effect of 5-HT showed a rapid onset, and a long period of washout was required before recovery (Fig. 4C). A consistent and significant reduction of the amplitude of dorsal column-evoked EPSPs was obtained in all giant interneurons studied (Fig. $4 D ; n=10 ; 33 \% \pm 3 \% ; p<0.0001$ ).

\section{5-HT does not alter AMPA-induced depolarization in giant interneurons}

The depression of sensory-evoked monosynaptic EPSPs by 5-HT was not associated with any change in the input resistance of giant interneurons near resting potentials (Figs. 2B, 3B, 4B). This suggests that the 5-HT effect on the amplitude of monosynaptic EPSPs is mediated by an action on presynaptic sensory afferents. 5-HT may, however, affect the amplitude of the EPSPs by altering the sensitivity of postsynaptic receptors. Such a possibility was tested by examining the response of giant interneurons to application of AMPA in control conditions and during application of 5-HT. AMPA was used in these experiments because sensoryevoked EPSPs in giant interneurons are mediated by activation of AMPA receptors (Christenson and Grillner, 1991). TTX (1 $\mu \mathrm{M})$ was perfused to block synaptic transmission while AMPA (1 mM) was applied through a pressure ejection pipette. A brief local application of AMPA induced a transient depolarization in the recorded giant interneuron, which was not significantly altered after bath application of 5-HT (Fig. 5A,B).

\section{5-HT inhibits spontaneous EPSPs in giant interneurons}

The effect of 5-HT on the amplitude of spontaneous EPSP recorded in giant interneurons also was tested. These experiments were done in normal Ringer's solution to allow for both mono- and polysynaptic transmission. All giant interneurons studied $(n=4)$ received spontaneous EPSPs (Fig. 6A), which reversibly decreased in amplitude 


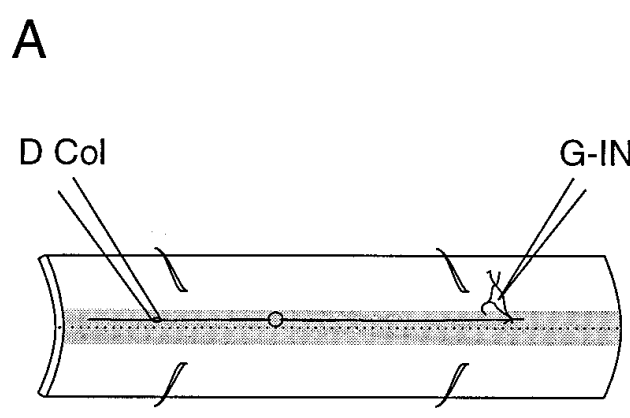

C

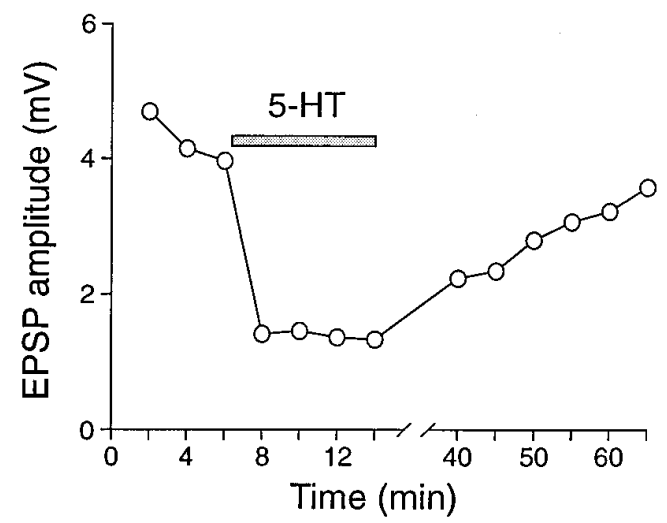

B
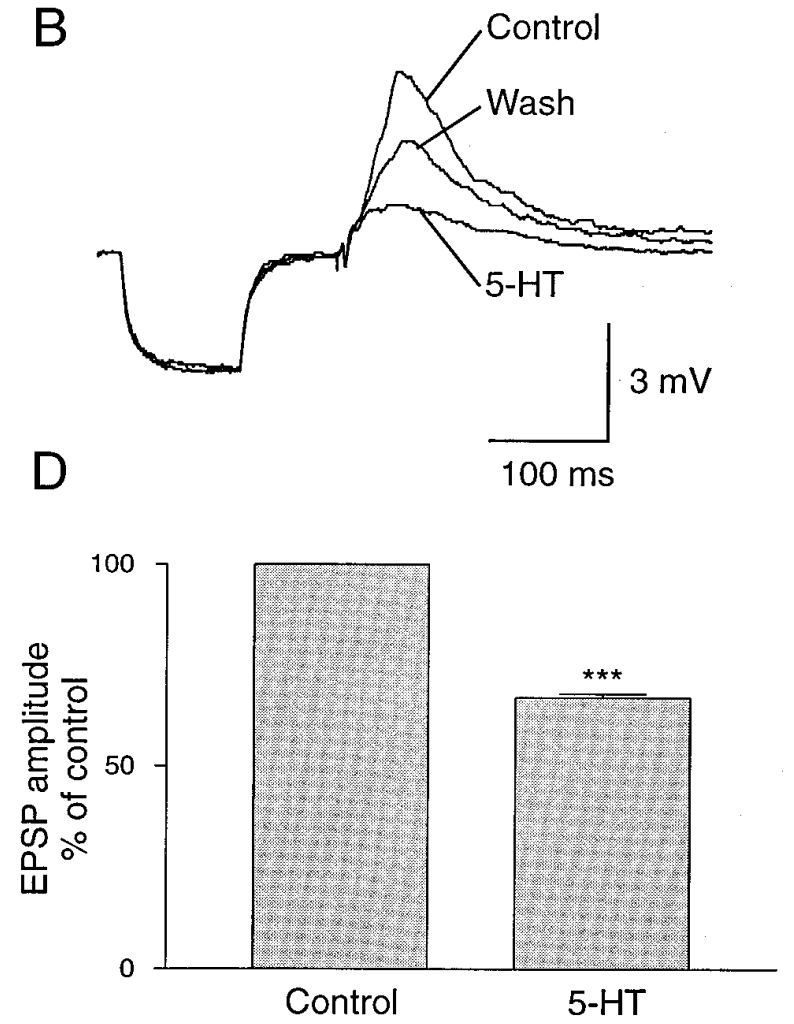

Figure 4. Effect of 5-HT on dorsal column synaptic transmission. A, Experimental setup. B, 5-HT decreased the amplitude of the compound EPSPs elicited in a giant interneuron by stimulation of dorsal column. No effect was observed on the input resistance. Traces are averages of 30 sweeps. $C$, Time course of the effect of 5-HT on dorsal column EPSP. D, Mean decrease of the amplitude of the dorsal column-evoked EPSPs in 10 different giant interneurons. The asterisks indicate statistical significance $(p<0.0001)$.

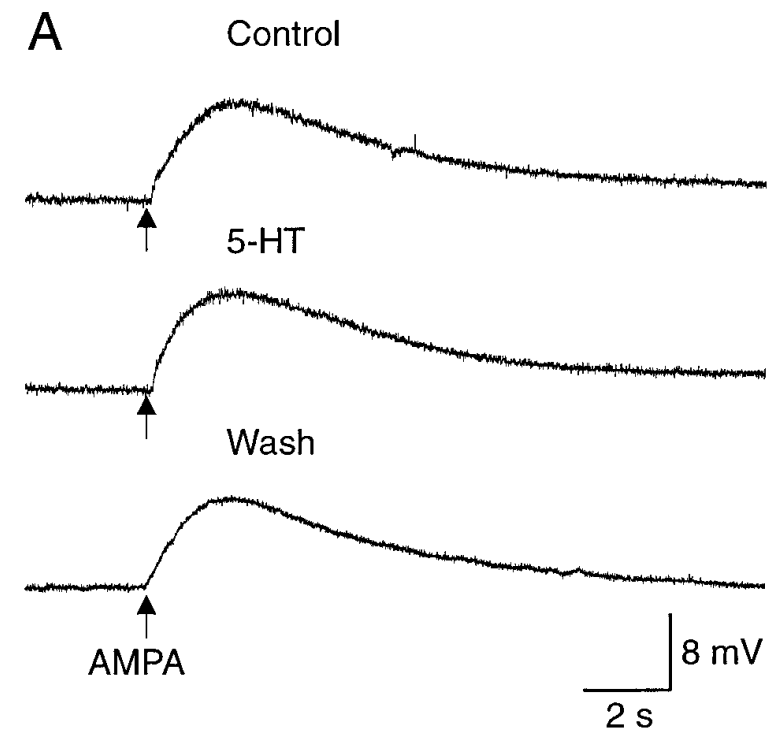

B

Figure 5. Lack of effect of 5-HT on AMPA-induced depolarizations in giant interneurons. $A$, Intracellular recording was made from a giant interneuron in TTX $(1 \mu \mathrm{M})$ to block synaptic transmission. Local pressure application of AMPA (1 mM) through an ejection pipette induced a depolarization of the membrane potential of the giant interneuron. The amplitude of the depolarization was not altered during application of 5-HT (5 $\mu \mathrm{M})$. $B$, Plot of the amplitude of AMPA-induced depolarizations from three different giant interneurons before, during, and after application of 5-HT (5 $\mu \mathrm{M})$, showing no significant change in the amplitude. 


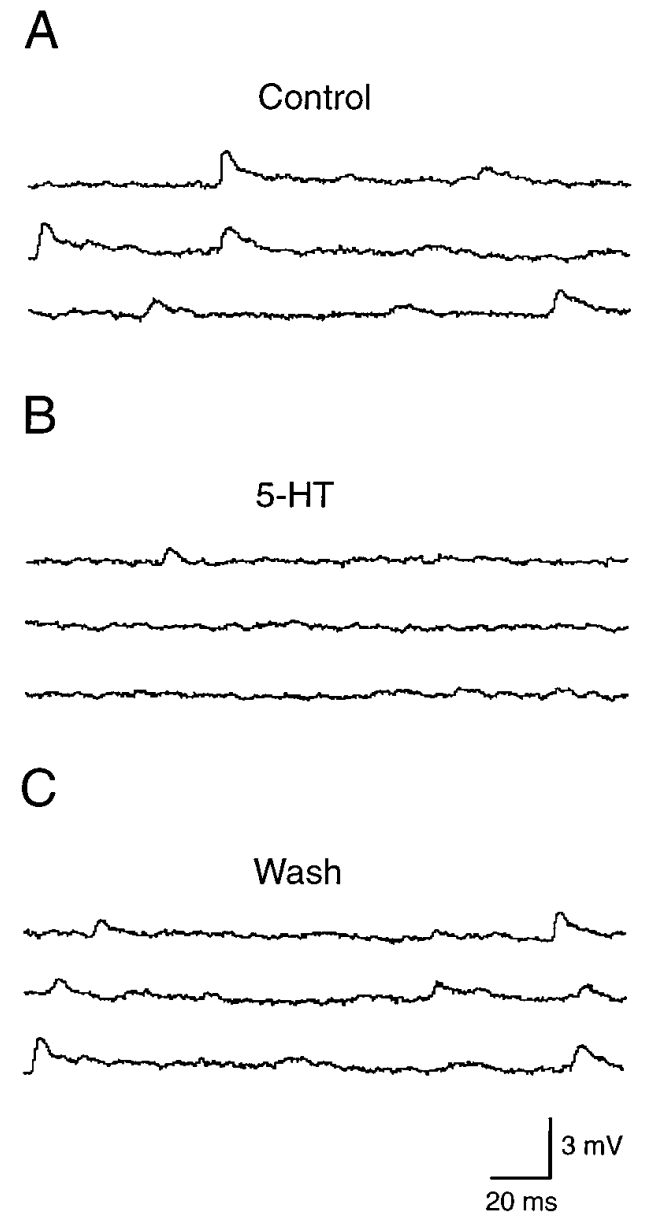

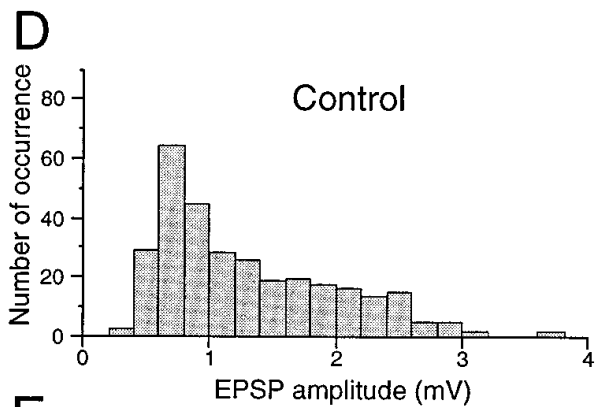
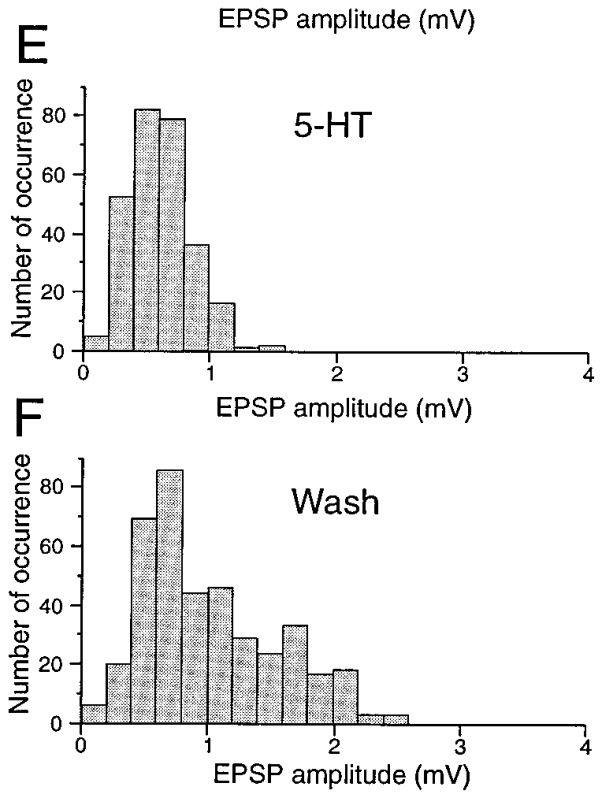

Figure 6. 5-HT reduces the amplitude of spontaneous EPSPs in giant interneurons. $A$, Spontaneous EPSPs recorded in a giant interneuron in control conditions. $B, 5$-HT depressed the amplitude of spontaneous EPSPs. $C$, The amplitude of spontaneous EPSPs recovered after washout. $D-F$, Distribution of the amplitude of spontaneous EPSPs before, during, and after application of 5-HT. The histograms in $D-F$ represent the amplitude of synaptic events that were identified clearly as EPSPs measured over a period of time of $5 \mathrm{~min}$ before, during, and after bath application of 5-HT. and frequency after 5-HT application (Fig. 6B,C). Under control conditions, the amplitude of spontaneous EPSPs ranged between 0.25 and $3.76 \mathrm{mV}$ (mean $=1.3 \pm 0.04 \mathrm{mV}$; Fig. 6D). During application of 5-HT, the amplitude of spontaneous EPSPs decreased significantly $(p<0.0001)$ and ranged between 0.1 and $1.4 \mathrm{mV}$ (mean $=0.62 \pm 0.01 \mathrm{mV}$; Fig. $6 E$ ). The amplitude of spontaneous EPSPs recovered after washout of 5-HT to values between 0.2 and $2.6 \mathrm{mV}($ mean $=1.02 \mathrm{mV} \pm 0.02 \mathrm{mV}$; Fig. $6 F$ ). 5-HT thus decreases the amplitude of both evoked and spontaneous EPSPs in giant interneurons.

\section{5-HT inhibits calcium current in dorsal cells}

The inhibition of synaptic transmission from dorsal cells and other sensory afferents could be mediated by a blockade of voltageactivated calcium channels. This was tested by using whole-cell recordings from identified dorsal cells in culture. Voltageactivated calcium channel current was elicited by depolarizing steps to $-10 \mathrm{mV}$ from a holding potential of $-90 \mathrm{mV}$, using barium as the charge carrier. Application of 5-HT $(1 \mu \mathrm{M})$ reversibly inhibited the calcium channel current (Fig. 7A,B). 5-HT also decreased the rate of activation of the whole-cell calcium channel current; the current at the beginning of voltage steps was inhibited more than the current at the end of the steps (Fig. 7A). Similar effects were obtained in all neurons tested (Fig. $7 C ; n=5$; mean reduction $=21.4 \% \pm 4.7 \% ; p<0.0001)$. These results show that dorsal cells possess 5-HT receptors, which decrease calcium influx through voltage-activated channels.

\section{5-HT-induced depression of sensory transmission is not mediated via $5-\mathrm{HT}_{1 \mathrm{~A}}$-like receptors}

5-HT depresses calcium-dependent potassium channels in network interneurons and decreases the frequency of the locomotor rhythm (Harris-Warrick and Cohen, 1985; Wallén et al., 1989) through activation of 5-HT $\mathrm{AA}_{\mathrm{A}}$-like receptors (Wikström et al., 1995). We used a $5-\mathrm{HT}_{1 \mathrm{~A}}$ antagonist to test whether the effect of 5-HT on sensoryevoked monosynaptic EPSPs in giant interneurons also would involve this type of 5-HT receptors. Application of the 5- $\mathrm{HT}_{1 \mathrm{~A}}$ antagonist $S(-)$-UH301 (1 $\mu \mathrm{M})$ decreased the amplitude of the EPSP evoked by dorsal root or dorsal column stimulation, and addition of 5-HT $(5 \mu \mathrm{M})$ induced a further decrease of the EPSP (Fig. $8 A$ ). The amplitude of the monosynaptic EPSP was depressed further when the concentration of the antagonist was increased, and addition of 5-HT was still able to reduce the amplitude of the EPSP (Fig. 8A,B). These results indicate that 5-HT depresses synaptic transmission through receptors that are different from those used to modulate the firing properties of network neurons and the frequency of the locomotor rhythm. Furthermore, the 5-HT $1 \mathrm{~A}$ antagonist used seems to have an agonistic effect on synaptic transmission.

\section{Dopamine does not affect sensory transmission}

5-HT and dopamine are colocalized in neurons in the ventromedial part of the spinal cord and in the plexus; they have complementary effects on calcium-dependent potassium channels and locomotor frequency (Schotland et al., 1995). The dorsal column, on the other hand, contains only 5-HT-ir fibers but no dopamine-ir fibers (Schot- 
A
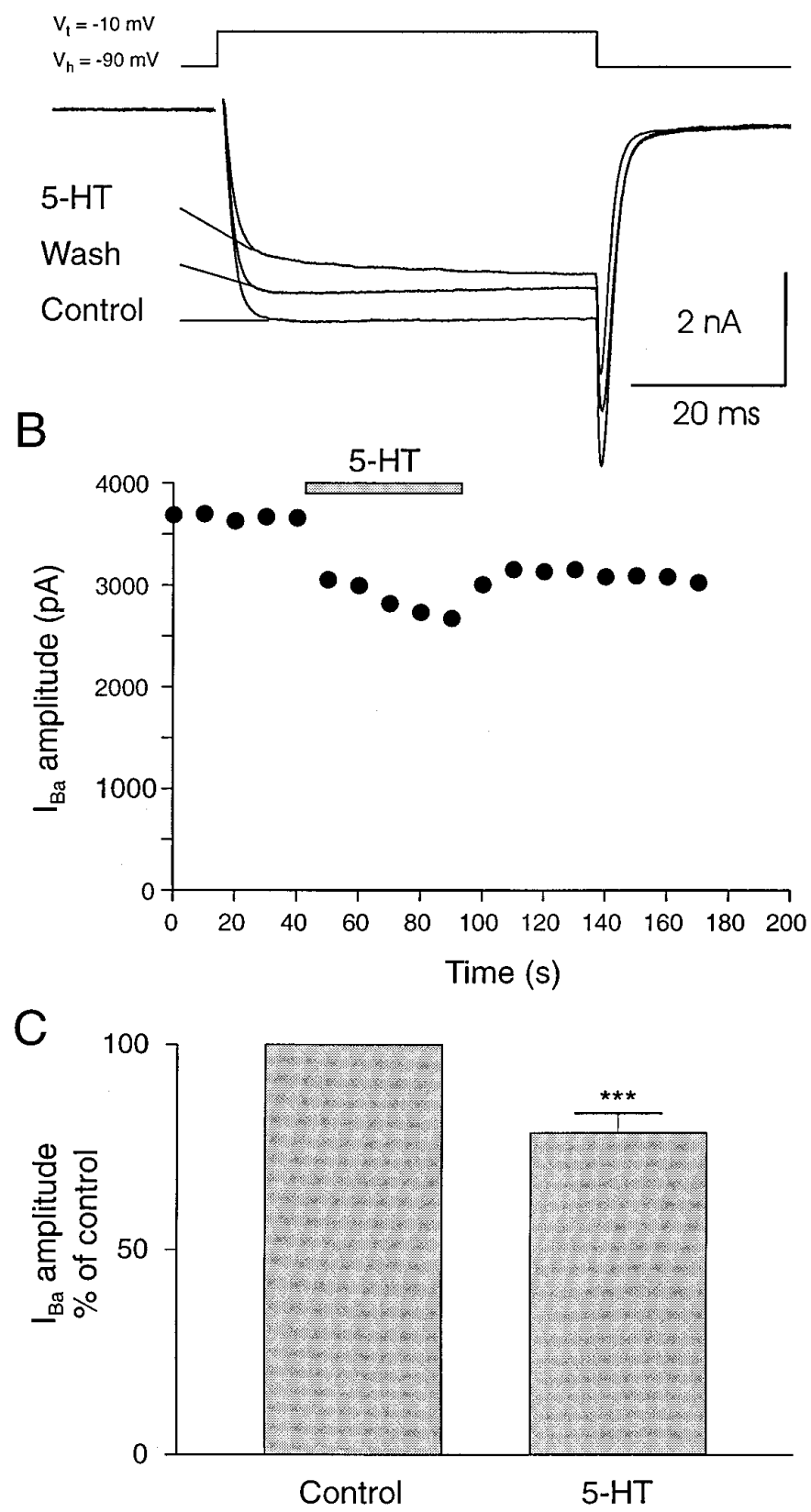

Figure 7. 5-HT inhibits high-voltage calcium channel current in dorsal cells. $A$, Whole-cell recording was made from a dorsal cell in culture, and inward barium current was elicited by a voltage step to $-10 \mathrm{mV}$ from a holding potential of $-90 \mathrm{mV}$. 5-HT $(1 \mu \mathrm{M})$ reversibly decreased the amplitude of the barium current and slowed its rate of activation. $B$, Plot of the amplitude, measured at the steady-state level, of barium current before, during, and after application of 5-HT. C, Plot of the mean effect of 5 -HT on six different dorsal cells. The asterisks indicate statistical significance $(p<0.0001)$.

land et al., 1995). It was, therefore, important to test whether dopamine would influence sensory synaptic transmission from dorsal roots and the dorsal column to determine whether the lack of dopamine-ir in the dorsal column is correlated with the absence of functional effect of dopamine on sensory synaptic transmission. Compound monosynaptic EPSPs were elicited in giant interneurons by dorsal root or dorsal column stimulation (Fig. 8C). Application of dopamine $(200 \mu \mathrm{M})$ did not change the amplitude of monosynaptic EPSPs (Fig. 8C,D; $n=6$ ). The absence of dopamine-ir in the dorsal column thus correlates with the lack of functional effect of dopamine on sensory transmission.

\section{DISCUSSION}

\section{5-HT varicose fibers make close appositions with dorsal cell axons}

In the present study we show that 5-HT-ir fibers in the dorsal column make close appositions with dorsal cells. A majority of contacts were found on axons, whereas fewer contacts were on the soma. 5-HT-ir fibers in the dorsal column originate from small cells present in dorsal root ganglia, which also show immunoreactivity against calcitonin gene-related peptide (CGRP) and bombesin (Van Dongen et al., 1985; Brodin et al., 1988). The 5-HT-ir fibers project both rostrally and caudally over several segments (Zhang et al., 1996). The type of sensory information carried by 5 -HT-ir cells in dorsal root ganglia is still unknown, but it has been suggested that they could be involved in nociception (Zhang et al., 1996). The ventromedial 5-HT/DA neurons do not form output synapses (Christenson et al., 1990; Schotland et al., 1996). They release 5-HT in a paracrinic fashion and affect the firing properties of spinal neurons and thereby the overall activity of the locomotor network (Christenson et al., 1989). Because no point-to-point 5-HT synapses have been found in the spinal cord, sensory axons in the dorsal column also might release 5-HT in a paracrinic fashion and affect dorsal cell and other sensory axons through volume transmission. Dorsal cell axons also have close appositions with NPY- and GABA-ir varicose fibers (Bongianni et al., 1990; Christenson et al., 1991). In addition, axo-axonic synapses have been found between GABA-ir terminals and dorsal column axons (Christenson et al., 1993). Both NPY and GABA $_{B}$ receptors mediate presynaptic inhibition of sensory transmission (Christenson and Grillner, 1991; D. Parker, unpublished observations). NPY and GABA presynaptic inputs to sensory axons arise from local spinal interneurons, which may allow the locomotor network to control the excitability of sensory afferents to avoid perturbation of ongoing activity by sensory feedback. 5-HT-ir fibers are, on the other hand, carrying sensory inputs and thus may be responsible for sensory-sensory interactions.

\section{5-HT modulation of sensory transmission}

5-HT decreased the amplitude of monosynaptic EPSPs elicited in giant relay interneurons by stimulation of dorsal cells, dorsal roots, and the dorsal column. The depression of EPSPs occurred without any detectable change in the input resistance or, when present, the electrical component of the EPSPs. The reduction of the amplitude of monosynaptic EPSPs is thus not attributable to a decrease of the input resistance of giant interneurons, which otherwise might shunt the EPSPs. We cannot, however, eliminate the possibility of a local conductance change occurring at a site too far from our somatic recording site. This seems unlikely, because the electrical component of the EPSPs was not affected. Excitatory synaptic transmission between sensory afferents and giant interneurons is mediated by activation of AMPA receptors (Christenson and Grillner, 1991). 5-HT could reduce the sensitivity of postsynaptic AMPA receptors and thus decrease the amplitude of sensory-evoked EPSPs. In such a case, 5-HT also should affect the AMPA-induced depolarization in giant interneurons. Our results show that this was not the case, because 5-HT failed to alter the responsiveness of giant interneurons to application of AMPA. Taken together, these results suggest that the depression 

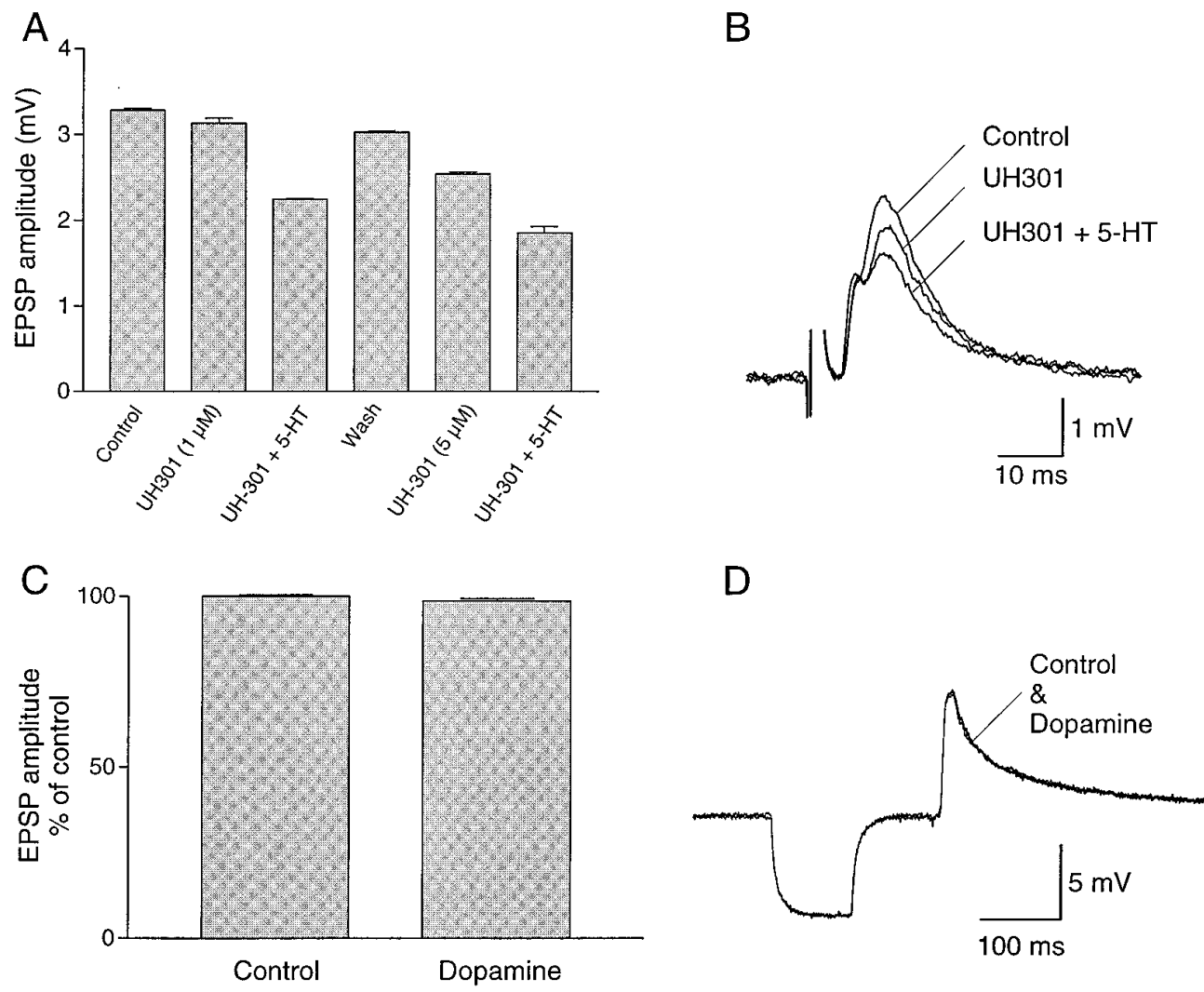

Figure 8. Dopamine does not affect sensory synaptic transmission to giant interneurons. $A$, Plot of the amplitude of monosynaptic EPSP in a giant interneuron, evoked by stimulation of a dorsal root, showing that the $5-\mathrm{HT}_{1 \mathrm{~A}}$ antagonist $S(-)$-UH301 did not counteract the 5-HT-mediated reduction of the amplitude of the EPSP. $B$, The $5-\mathrm{HT}_{1 \mathrm{~A}}$ antagonist $S(-)$-UH301 decreased the amplitude of the EPSP, and addition of 5-HT reduced the EPSP further. $C$, The amplitude of sensory-evoked EPSPs was not affected by dopamine ( $200 \mu \mathrm{M} ; n=6)$. $D$, The amplitude of compound EPSP recorded in a giant interneuron by stimulation of dorsal column is not affected by dopamine. of monosynaptic EPSPs is mediated by 5-HT receptors located on the presynaptic axons of sensory neurons. The endogenous 5-HT is likely to be released from the sensory varicose fibers that make close appositions with dorsal cell axons.

5-HT previously has been shown to act through $5-\mathrm{HT}_{1 \mathrm{~A}}$-like receptors to reduce the amplitude of the slow afterhyperpolarization (sAHP) after action potentials and thus regulates the firing frequency of spinal neurons (Wikström et al., 1995). In the present study, we show that the 5-HT 1 a antagonist $S(-)-\mathrm{UH} 301$, which blocks the effect of 5-HT on the sAHP, fails to counteract the effect of 5-HT on sensory synaptic transmission. The depression of synaptic transmission by 5-HT thus is mediated by receptors pharmacologically different from $5-\mathrm{HT}_{1 \mathrm{~A}}$. Furthermore, the presynaptic effect required higher concentrations of 5-HT (1-5 $\mu \mathrm{M})$, as compared to the postsynaptic effect on the sAHP that was manifested already at $100 \mathrm{~nm}$. The differences in sensitivity to $5-\mathrm{HT}_{1 \mathrm{~A}}$ antagonists and effective concentrations of 5-HT strongly suggest that the pre- and postsynaptic effects of 5-HT are mediated by two different types of receptors.

In the rat brain, 5-HT-mediated presynaptic inhibition of glycinergic and GABAergic transmission is mediated through activation of 5- $\mathrm{HT}_{1 \mathrm{~B}}$ receptors (Johnson et al., 1992; Umemiya and Berger, 1995). In Xenopus, 5-HT presynaptically inhibits sensory transmission and increases the threshold for induction of swimming activity by sensory stimulation (Sillar and Simmers, 1994b). 5-HT also has been shown to induce presynaptic facilitation of sensory transmission. In Aplysia, 5-HT induces facilitation of both evoked and spontaneous release from sensory neurons (Dale and Kandel, 1990; Eliot et al., 1993). Furthermore, 5-HT-induced facilitation of quantal release has been shown for brainstem inhibitory transmission in goldfish (Mintz and Korn, 1991). In the mollusc Tritonia, stimulation of a single 5-HT neuron induced presynaptic facilitation of synaptic transmission from another interneuron in the network controlling swimming behavior (Katz and Frost, 1995). In the lamprey, 5-HT mediates presynaptic inhibition in reticulospinal axons (Buchanan and Grillner, 1991; Shupliakov et al., 1995), whereas synaptic transmission from excitatory and inhibitory network interneurons is not affected by 5-HT (Buchanan and Grillner, 1991; Matsushima and Grillner, 1992).

\section{5-HT inhibition of calcium current}

5 -HT reduced the amplitude of high-voltage calcium current in dorsal cells in culture. The decrease in the amplitude of the current was much greater at the beginning of the voltage step than at the end. This slowing in kinetics is a common feature of calcium current inhibition because of G-protein-coupled receptors (Hille, 1994; Dolphin, 1996). This mode of action is likely to produce a strong inhibition of calcium influx during action potentials and thereby may cause a potent inhibition of transmitter release that requires a fast and local increase of the calcium concentration. The depression of calcium current by 5-HT, as revealed in wholecell voltage-clamp experiments, demonstrates the existence of functional 5-HT receptors on dorsal cell somata. It is thus possible that 5-HT receptor activation inhibits sensory synaptic transmission by directly reducing calcium influx through HVA calcium channels at the presynaptic axons. 5-HT also can depress synaptic transmission by directly affecting the secretory pathway subsequent to calcium entry. Such a mechanism has been suggested for 5-HT-mediated presynaptic inhibition in Xenopus, because the reduction of both the frequency of spontaneous miniature EPSPs and the amplitude of sensory-evoked EPSP displayed the same time course (Sillar and Simmers, 1994b). In lamprey reticulospinal neurons, 5-HT inhibition of synaptic release occurs without any apparent effect on calcium entry (Shupliakov et al., 1995). 


\section{Conclusions}

5-HT immunoreactive fibers arising from dorsal root ganglion cells make close appositions with dorsal cell axons. Exogenous application of 5-HT depresses the amplitude of monosynaptic EPSPs, most likely through presynaptic mechanisms, and inhibits calcium channel current in the soma of dorsal cells. It thus seems likely that the small 5-HT sensory neurons in dorsal root ganglia can control transmission from cutaneous as well as other sensory neurons directly. This may represent a mechanism for sensorysensory interactions that, under certain conditions, may inhibit sensory transmission from large sensory neurons.

\section{REFERENCES}

Anwyl R (1990) Neurophysiological actions of 5-hydroxytryptamine in the vertebrate nervous system. Prog Neurobiol 35:451-468.

Barbeau H, Rossignol S (1990) The effects of serotonergic drugs on the locomotor pattern and on cutaneous reflexes of the adult chronic spinal cat. Brain Res 514:55-67.

Bongianni F, Christenson J, Hökfelt T, Grillner S (1990) Neuropeptide Y-immunoreactive spinal neurons make close appositions on axons of primary sensory afferents. Brain Res 523:337-341.

Brodin L, Christenson J, Grillner S (1987) Single sensory neurons activate excitatory amino acid receptors in the lamprey spinal cord. Neurosci Lett 75:75-79.

Brodin L, Buchanan JT, Hökfelt T, Grillner S, Rehfeld JF, Frey P, Verhofstad AA, Dockray GJ, Walsh JH (1988) Immunohistochemical studies of cholecystokinin-like peptides and their relation to 5-HT, CGRP, and bombesin immunoreactivities in the brainstem and spinal cord of lampreys. J Comp Neurol 271:1-18.

Buchanan JT, Grillner S (1991) 5-Hydroxytryptamine depresses reticulospinal excitatory postsynaptic potentials in motoneurons of the lamprey. Neurosci Lett 122:71-74.

Christenson J, Grillner S (1991) Primary afferents evoke excitatory amino acid receptor-mediated EPSPs that are modulated by presynaptic $\mathrm{GABA}_{\mathrm{B}}$ receptors in lamprey. J Neurophysiol 66:2141-2149.

Christenson J, Franck J, Grillner S (1989) Increase in endogenous 5-hydroxytryptamine levels modulates the central network underlying locomotion in the lamprey spinal cord. Neurosci Lett 100:188-192.

Christenson J, Cullheim S, Grillner S, Hökfelt T (1990) 5-Hydroxytryptamine immunoreactive varicosities in the lamprey spinal cord have no synaptic specializations-an ultrastructural study. Brain Res 512:201-209.

Christenson J, Bongianni F, Grillner S, Hökfelt T (1991) Putative GABAergic input to axons of spinal interneurons and primary sensory neurons in the lamprey spinal cord as shown by intracellular Lucifer yellow and GABA immunohistochemistry. Brain Res 538:313-318.

Christenson J, Shupliakov O, Cullheim S, Grillner S (1993) Possible morphological substrates for GABA-mediated presynaptic inhibition in the lamprey spinal cord. J Comp Neurol 328:463-472.

Dale N, Kandel ER (1990) Facilitatory and inhibitory transmitters modulate spontaneous transmitter release at cultured Aplysia sensorimotor synapses. J Physiol (Lond) 421:203-222.

Dolphin AC (1996) Facilitation of $\mathrm{Ca}^{2+}$ current in excitable cells. Trends Neurosci 19:35-43.

Eliot LS, Kandel ER, Siegelbaum SA, Blumenfeld H (1993) Imaging terminals of Aplysia sensory neurons demonstrates role of enhanced $\mathrm{Ca}^{2+}$ influx in presynaptic facilitation. Nature 361:634-637.

Grillner S, Deliagina T, Ekeberg Ö, El Manira A, Hill RH, Lansner A, Orlovsky GN, Wallén P (1995) Neural networks that co-ordinate locomotion and body orientation in lamprey. Trends Neurosci 18:270-279.

Harris-Warrick RM, Cohen AH (1985) Serotonin modulates the central pattern generator for locomotion in the isolated lamprey spinal cord. J Exp Biol 116:27-46.

Harris-Warrick RM, Marder E (1991) Modulation of neural networks for behavior. Annu Rev Neurosci 14:39-57.

Harris-Warrick RM, McPhee JC, Filler JA (1985) Distribution of serotonergic neurons and processes in the lamprey spinal cord. Neuroscience 14:1127-1140.

Hille B (1994) Modulation of ion-channel function by G-protein-coupled receptors. Trends Neurosci 17:531-535.

Hori Y, Endo K, Takahashi T (1996) Long-lasting synaptic facilitation induced by serotonin in superficial dorsal horn neurones in the rat spinal cord. J Physiol (Lond) 492:867-876.
Hounsgaard J, Kiehn O (1989) Serotonin-induced bistability of turtle motoneurones caused by a nifedipine-sensitive calcium plateau potential. J Physiol (Lond) 414:265-282.

Jacobs BL, Fornal CA (1993) 5-HT and motor control: a hypothesis. Trends Neurosci 16:346-352.

Johnson SW, Mercuri NB, North A (1992) 5-Hydroxytryptamine ${ }_{1 B}$ receptors block the $\mathrm{GABA}_{\mathrm{B}}$ synaptic potential in rat dopamine neurons. J Neurosci 12:2000-2006.

Katz PS, Frost WN (1995) Intrinsic neuromodulation in the Tritonia swim CPG-the serotonergic dorsal swim interneurons act presynaptically to enhance transmitter release from interneuron $\mathrm{C} 2$. J Neurosci 15:6035-6045.

Katz PS, Frost WN (1996) Intrinsic neuromodulation-altering neuronal circuits from within. Trends Neurosci 19:54-61.

Katz PS, Getting PA, Frost WN (1994) Dynamic neuromodulation of synaptic strength intrinsic to a central pattern generator circuit. Nature 367:729-731.

Matsushima T, Grillner S (1992) Local serotonergic modulation of calcium-dependent potassium channels controls intersegmental coordination in the lamprey spinal cord. J Neurophysiol 67:1683-1690.

Mintz I, Korn H (1991) Serotonergic facilitation of quantal release at central inhibitory synapses. J Neurosci 11:3359-3370.

Rovainen CM (1967) Physiological and anatomical studies on large neurons of central nervous system of the sea lamprey (Petromyzon marinus). II. Dorsal cells and giant interneurons. J Neurophysiol 30:1024-1042.

Sah DWY (1990) Neurotransmitter modulation of calcium current in rat spinal cord neurons. J Neurosci 10:136-141.

Saudou F, Hen R (1994) 5-Hydroxytryptamine receptor subtypes in vertebrates and invertebrates. Neurochem Int 25:503-532.

Schotland J, Shupliakov O, Wikström M, Brodin L, Srinivasan M, You ZB, Herrera-Marschitz M, Zhang W, Hökfelt T, Grillner S (1995) Control of lamprey locomotor neurons by colocalized monoamine transmitters. Nature 374:266-268.

Schotland J, Shupliakov O, Grillner S, Brodin L (1996) Synaptic and nonsynaptic monoaminergic neuron systems in the lamprey spinal cord. J Comp Neurol 372:229-244.

Shupliakov O, Pieribone VA, Gad H, Brodin L (1995) Synaptic vesicle depletion in reticulospinal axons is reduced by 5-hydroxytryptaminedirect evidence for presynaptic modulation of glutamatergic transmission. Eur J Neurosci 7:1111-1116.

Sillar KT, Simmers AJ (1994a) 5-HT induces NMDA receptor-mediated intrinsic oscillations in embryonic amphibian spinal neurons. Proc R Soc Lond [Biol] 255:139-145.

Sillar KT, Simmers AJ (1994b) Presynaptic inhibition of primary afferent transmitter release by 5-hydroxytryptamine at a mechanosensory synapse in the vertebrate spinal cord. J Neurosci 14:2636-2647.

Sillar KT, Wedderburn JF, Simmers AJ (1992) Modulation of swimming rhythmicity by 5-hydroxytryptamine during post-embryonic development in Xenopus laevis. Proc R Soc Lond [Biol] 250:107-114.

Steinbusch HW, Verhofstad AAJ, Jootsten HWJ (1987) Localization of serotonin in the central nervous system by immunohistochemistry: description of a specific and sensitive technique and some applications. Neuroscience 3:811-819.

Umemiya M, Berger AJ (1995) Presynaptic inhibition by serotonin of glycinergic inhibitory synaptic currents in the rat brain stem. J Neurophysiol 73:1192-1200.

Van Dongen PA, Hökfelt T, Grillner S, Verhofstad AA, Steinbusch HW, Cuello AC, Terenius L (1985) Immunohistochemical demonstration of some putative neurotransmitters in the lamprey spinal cord and spinal ganglia: 5-hydroxytryptamine-, tachykinin-, and neuropeptide-Yimmunoreactive neurons and fibers. J Comp Neurol 234:501-522.

Wallén P, Buchanan JT, Grillner S, Hill RH, Christenson J, Hökfelt T (1989) Effects of 5-hydroxytryptamine on the afterhyperpolarization, spike frequency regulation, and oscillatory membrane properties in lamprey spinal cord neurons. J Neurophysiol 61:759-768.

Welsh JH, Moorhead M (1960) The quantitative distribution of 5-hydroxytryptamine in the invertebrates, especially in their nervous system. J Neurochem 6:146-169.

Wikström M, Hill R, Hellgren J, Grillner S (1995) The action of 5-HT on calcium-dependent potassium channels and on the spinal locomotor network in lamprey is mediated by $5-\mathrm{HT}_{1 \mathrm{~A}}$-like receptors. Brain Res 678:191-199.

Zhang W, Pombal MA, El Manira A, Grillner S (1996) Rostrocaudal distribution of 5-HT innervation in the lamprey spinal cord and differential effects of 5-HT on fictive locomotion. J Comp Neurol 374:278-290. 